\title{
The sedimentary features of Proterozoic microspar (Molar-tooth) carbonates in China and their significance
}

Institute of Sedimentary Basin, China University of Geosciences, Beijing, 100083, China. E-mail: mengxh@cugb.edu.cn

On the North China platform Molar-tooth (MT) carbonates were formed during 1600-650Ma (i.e. the Middle to Late Proterozoic), within various supercyclic sequences, such as the Changcheng, Jixian, Qingbaikou and Sinian Systems. Detailed field observations on the MT carbonate sections and microscopic studies show that MT carbonates may be divided into two major groups-autochthonous and allochthonous and 6 subgroups according to their depositional features. The autochthonous MT may be subdivided into four types, i.e. filamentous MT, curved banded MT, complicated sheet-like MT and dotted-tumorous MT, while the allochthonous MT may be subdivided into two types, i.e. mimicry-intraclastic MT and intraclastic MT. Based on sequence statistics and analysis of megascopic microfabrics, a sedimentary model of MT carbonates is proposed. MT structures occur within a range of facies from the subtidal to the basin margin zone. Various megascopic microfabrics may serve as useful environmental markers. MT structures might be a link to the revolutionary changes in the biosphere, which heralded the appearance of complex multi-cellular metazoan in the Late Precambrian. It is proposed that MT carbonates occupied the interval between Archean Times without life (but with an interval of inorganic aragonite, and tuff precipitation) and the Phanerozoic with skeletal carbonate precipitation. After a detailed discussion on many hypotheses for the origin of MT, and five evidences against their seismic origin it was concluded that the structures of MT carbonates are various and distributed so randomly that they may be related to the geological complexity. But the components of microsparite show MT's common characteristics, so the key to solve the origin of MT carbonates lies in the research on the origin of the microsparite. Hence, the most important factor for the origin of MT may be traced from the biological and geological evolutionary events of the Pre-Cambrian ocean. Most likely the formation of MT structure and microspar carbonates were terminated due to the obvious changes of particular organism and geochemistry in the paleo-oceanic environment of the Proterozoic in Phanerozoic era. A comprehensive study of MT carbonates will greatly enhance our understanding of the history of Proterozoic marine carbonate deposition as well as the history of early organic evolution. This forms the main objective of IGCP project 447.

\section{Introduction}

There is abundant evidence for the study of organic evolution in Precambrian sedimentary records, which help to interpret the early evolution of life. It is suggested that the existence of Molar-tooth (MT) structure was related to this.

Molar-tooth structures are contortedly folded and microsparfilled cracks in fine-grained carbonates of Precambrian age. The term was first used in the geological literature by Bauerman (1885) for structures "resembling the markings on the molar tooth of an elephant" in carbonates of the Belt Supergroup near the Canada-USA border in Western Montana. The structure consists chiefly of vertical, contortedly-folded sheets of finely crystalline calcite-spar in dolomitic lime mudstone (Smith 1968; O'Connor 1972; Furniss et al. 1997), but the present authors think that the structure also includes some microspar sheets and dotted line parallel to the bedding.

MT structures have been found in more than 40 countries and regions, including Canada, U.S.A, Europe, Australia, Africa, Siberia and China (in Tonghua-Hunjiang, Liaodong and Xu-Huai regions, nd the Yanshan Mountains). Since MT carbonates were formed in the distant Precambrian and are rare in younger deposits, their origin has been debated for over a century without reaching a consensus of opinion.

Studied area by the authors in the Lower Sinian include Wanlong Formation in Hunjiang, Jilin Province, Changlingzi, Nanguanling and Yingchengzi Formation in Jinxian, Liaoning Province and the Qingbaikouan Nanfung Formation in Benxi, the Sinian Jiayuan Formation, Zhao Formation, Jiudingshan Formation, Weiji Formation and Wangshan Formation in North Anhui (Figure 1). 


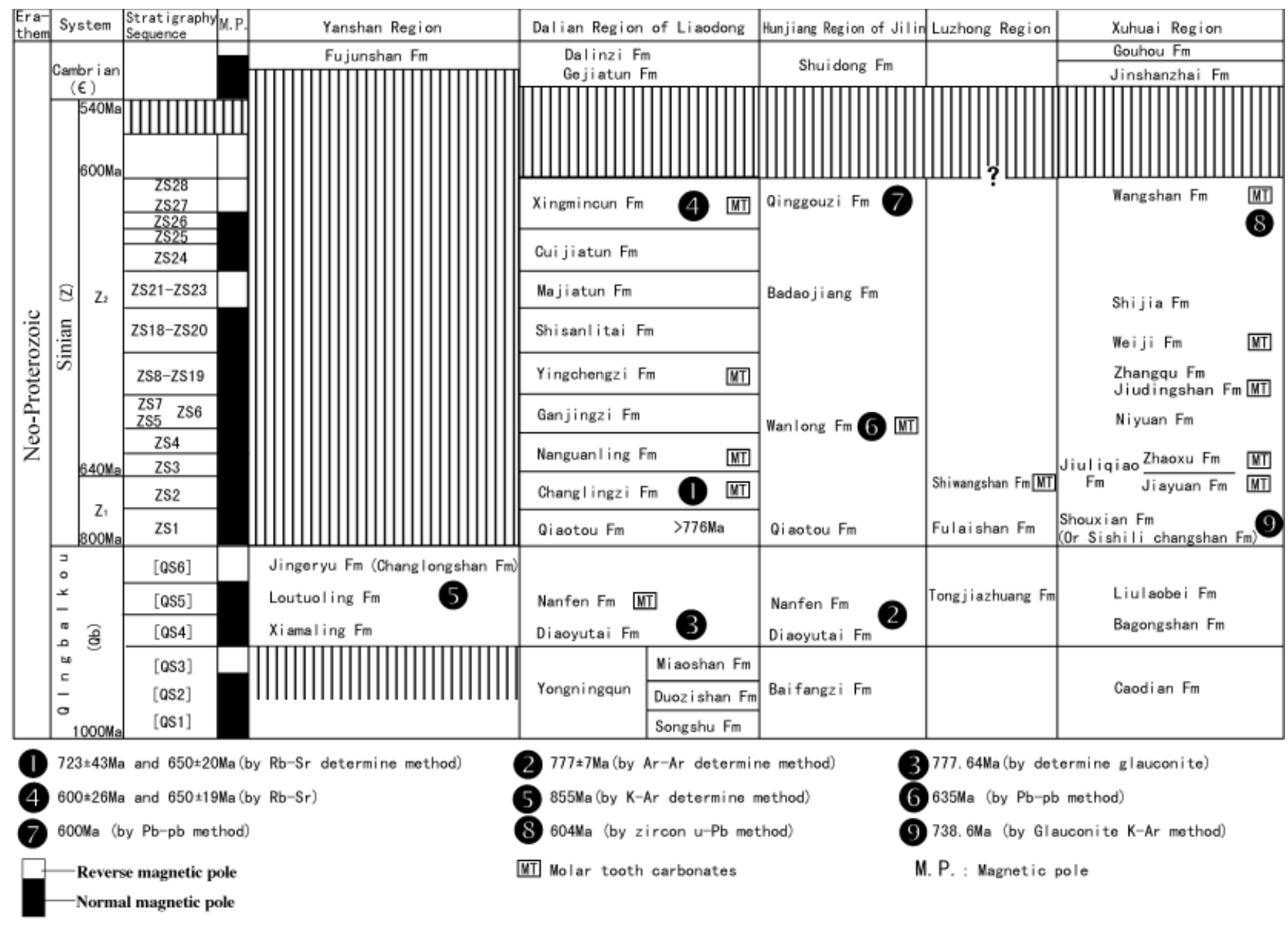

Figure 1 Comparison of Neoproterozoic sequence stratigraphy and distribution of MT carbonates in the eastern part of North China.

\section{The microspar (Molar-tooth) carbonates in the North China platform}

\section{Classification and megascopic features of MT limestone in the North China platform}

\section{Classification of MT carbonates}

Detailed field observations on the MT limestone sections and microscopic studies show that MT carbonates may be divided into two major groups: autochthonous and allochthonous and 6 subgroups (Figure 2). The autochthonous group may be further divided into 4 subgroups:

a) Filamentous type- - It is seen chiefly in argillaceous-sparry limestone, each reaches $1-10 \mathrm{~cm}$ long and $1-2 \mathrm{~mm}$ wide, mainly sub-

\begin{tabular}{|c|l|}
\hline Genesis & \multicolumn{1}{|c|}{ Structure-fabric } \\
\hline \multirow{4}{*}{$\begin{array}{c}\text { Autochthonous MT } \\
\text { (originally ptygmatical) }\end{array}$} & 1. Filamentous MT \\
\cline { 2 - 2 } & 2. Curved banded MT \\
\cline { 2 - 2 } & 3. Complicated sheet-like MT \\
\cline { 2 - 2 } 4. Tumorous MT \\
\hline \multirow{2}{*}{$\begin{array}{c}\text { Allochthonous MT } \\
\text { (Intraclastic) }\end{array}$} & $\begin{array}{l}\text { 1. Mimicry-intraclastic MT } \\
\text { (Subdivided by grain-sizc) }\end{array}$ \\
\hline
\end{tabular}

Figure 2 Structure-fabric classification of MT carbonates. vertical to bedding (Figure 3-6 ), appearing from the Middle Proterozoic to the Sinian.

b) Curved, banded type - Several to $10 \mathrm{~cm}$ long and $1-5 \mathrm{~mm}$ wide; bowed, hooked, molar-shaped, ptygmatical MT in cross-section, and the curved-banded MT extending towards the bedding plane, but mostly didn't penetrate them (Figure 3-1,3,4). This type was commonly developed in Late Proterozoic carbonates, such as the Wanlong Formation.

c) Complicated sheet-like type-Complicated and multi-superimposed molar-like, giving rise to an assemblage of multi-periodic parallel bands (sheets). Each reaches over $10 \mathrm{~cm}$ in length and 3$5 \mathrm{~mm}$ in width (Figure 7-3).

d) Dotted and Tumorous type-Dot-line-shaped and tumor-shaped microspar structures with irregular boundaries. Their distributive trends and extending directions are related to bedding, and also randomly distributed sometimes (Figure 4).

The four types presented above were developed one or two and more together in carbonates.

The allochthonous MT carbonates may be divided into two subgroups, i.e. mimicry-intraclastic MT (Figure 5) and intraclastic MT (Figure 6-2, 3, 4, 5, 6). The latter subgroup may be subdivided by grain-size.

\section{Micro-features of MT carbonates}

MT carbonates clearly differ from their carbonate matrix in terms of composition, texture, and mineralogy. The matrix is generally composed of impure argillo-sparry calcite, commonly containing clay and fine silt grains, whereas the interior of the MT structures was filled purely with micro-sparry calcite, whose crystal sizes are around $0.01 \mathrm{~mm}$ in diameter and texturally homogeneous. EDAX analysis shows that the matrix is dominated by $\mathrm{Ca}, \mathrm{Mg}, \mathrm{Al}, \mathrm{Si}, \mathrm{K}$, 

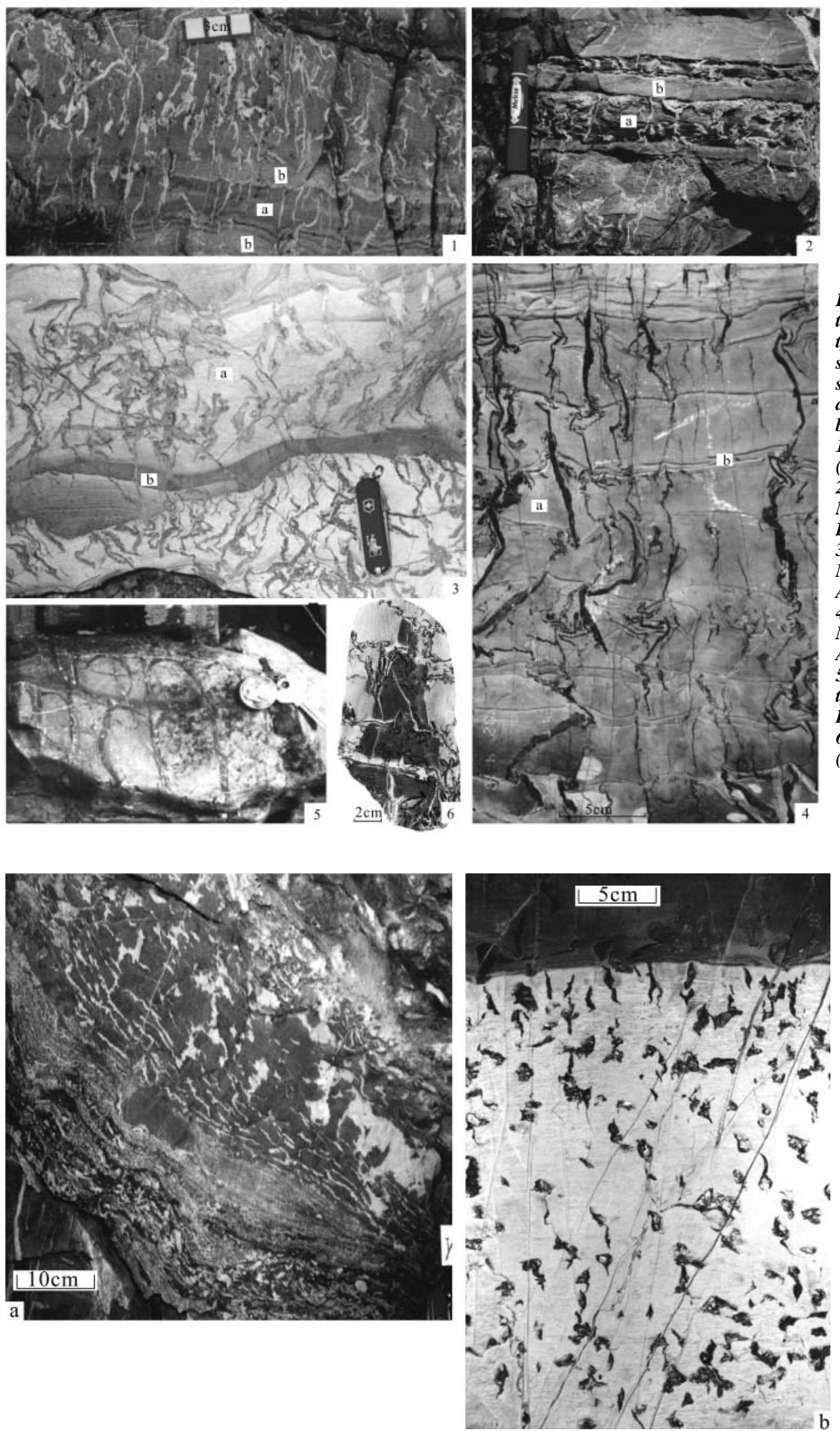
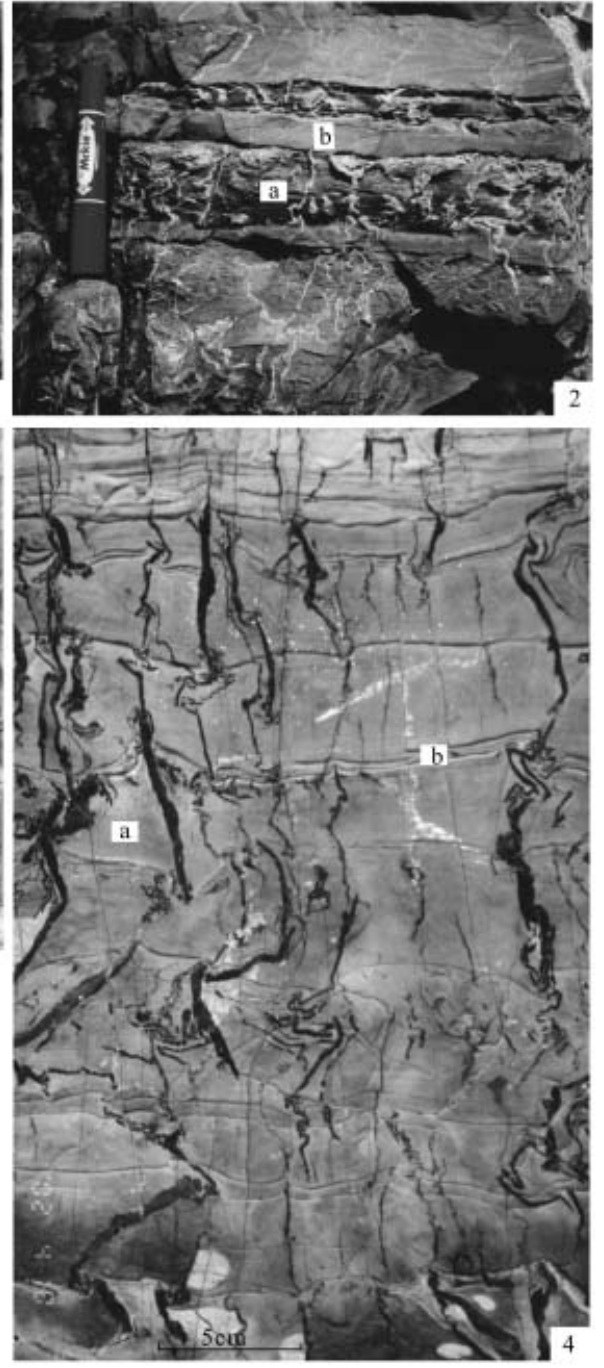

Figure 3 Autochthonous Molartooth carbonate: Filamentous type and curved type MT structure, showing the sedimentary control:

$a$-mudlimestone;

$b$-fine-grained mudstone.

1. Curved sheet-type: MF5 (Xingmincun Fm., Dalian);

2. Curved, bended type: MF4/ MF3 (Wanlong Fm., Jilin Province);

3. Curved, banded type: MF6/ MF7 (Jiudingshan Fm., Lingbi, Anhui Province);

4. Curved sheet-like: MF3 and MF5 (Jiudingshan Fm., Suzhou, Anhui Province);

5. Hook-like curved banded type, MF2 (Wanlong Fm., Baishan, Jilin Province);

6. Filamentous type: MF1 (Wanlong Fm., Jilin Province).

Figure 4 Dotted and tumorous type of autochthonous MT carbonates (Jiudingshan Formation, Lingbi, Anhui Province.)

a-Large dotted and tumorous type of autochthonous MT carbonates: The maximum diameter reaches $20 \mathrm{~cm}, M T 9$ (Yingchengzi Formation, Qipanmo section, Dalian); $b$-Little dotted and tumorous type of autochthonous MT (Anhui Province). 


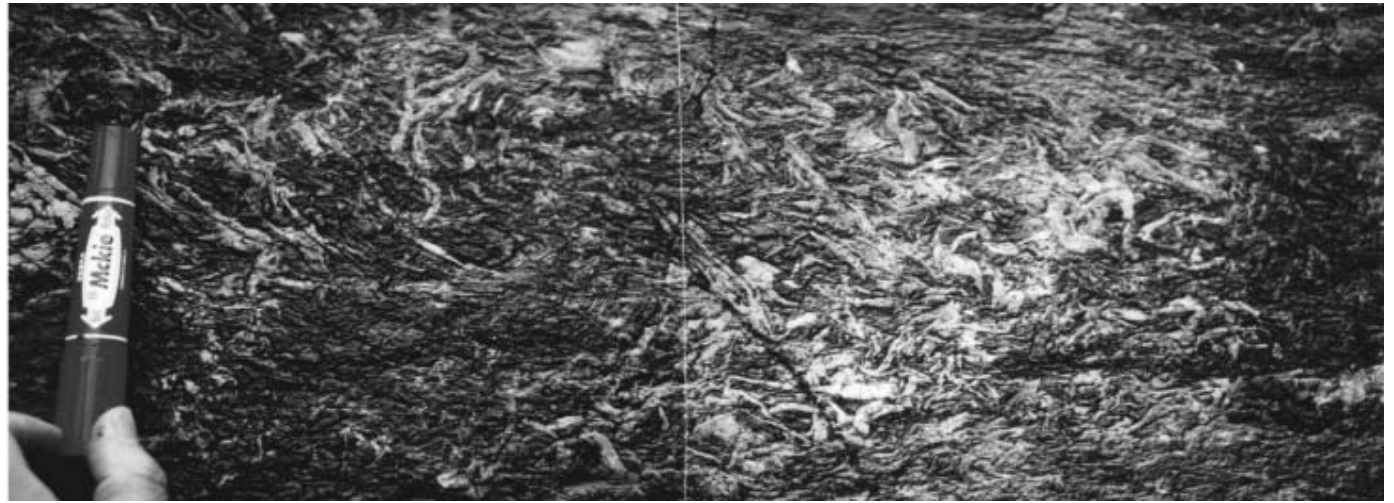

Figure 5 Minicry-intraclastic MT of allochthonous MT carbonates, MF10 (Wanlong Formation, Jilin Province, Northeast China).
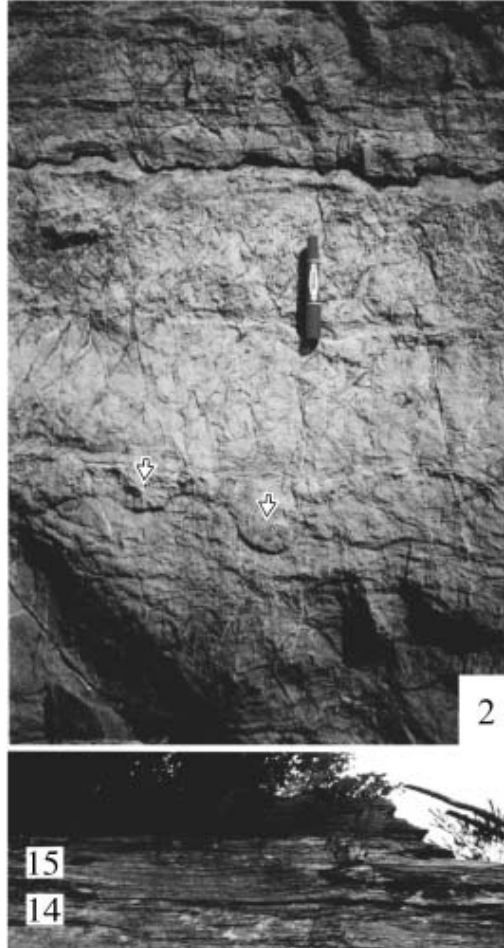

13 m.
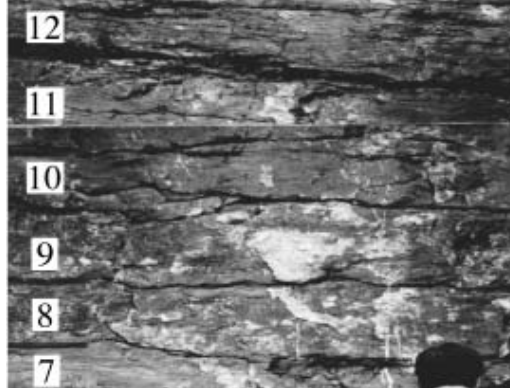

\section{7}

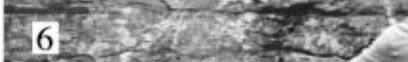

\section{5}

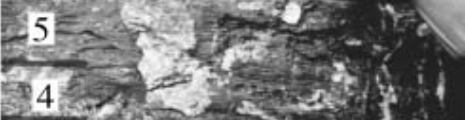

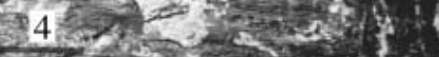

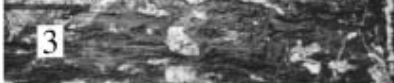
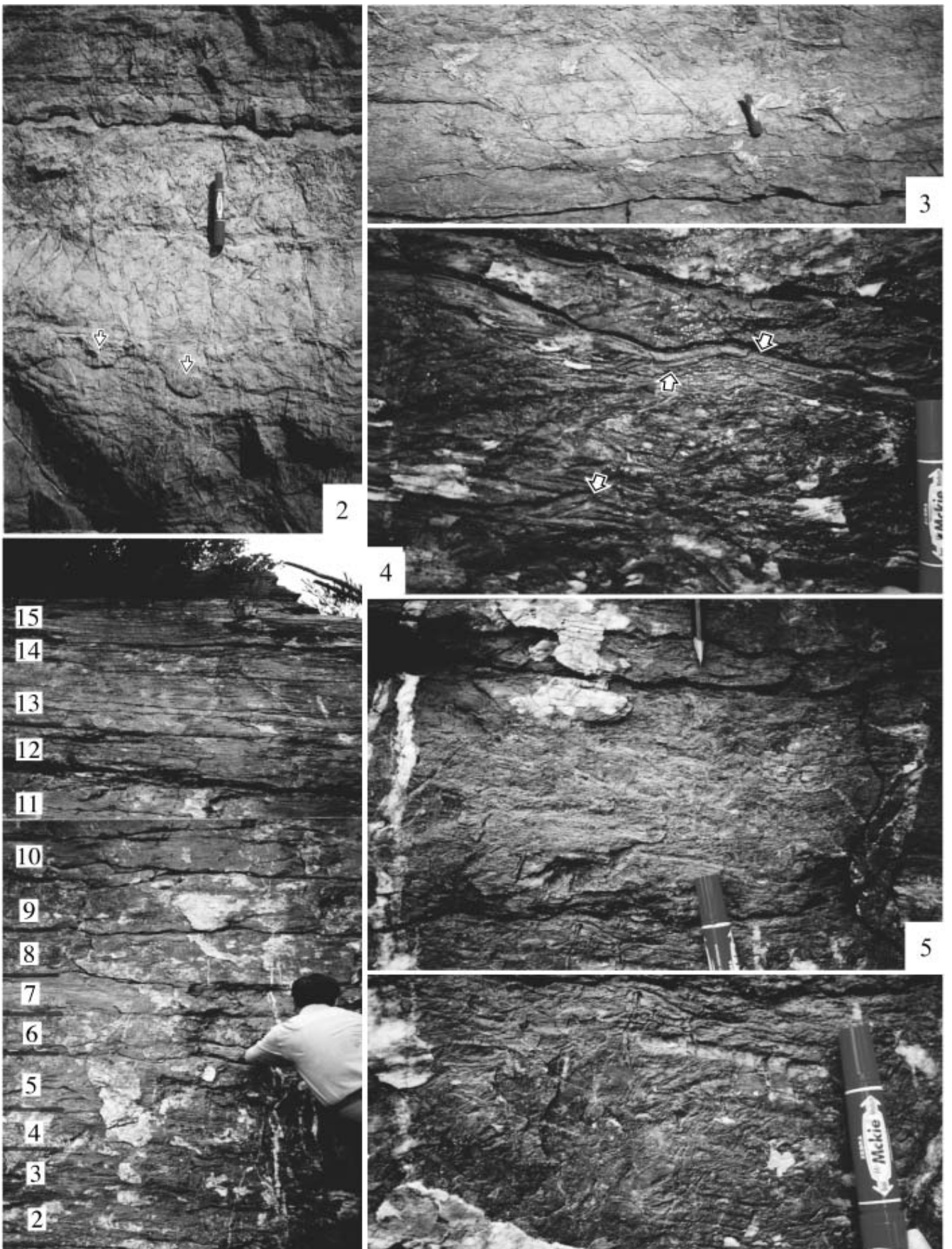

4
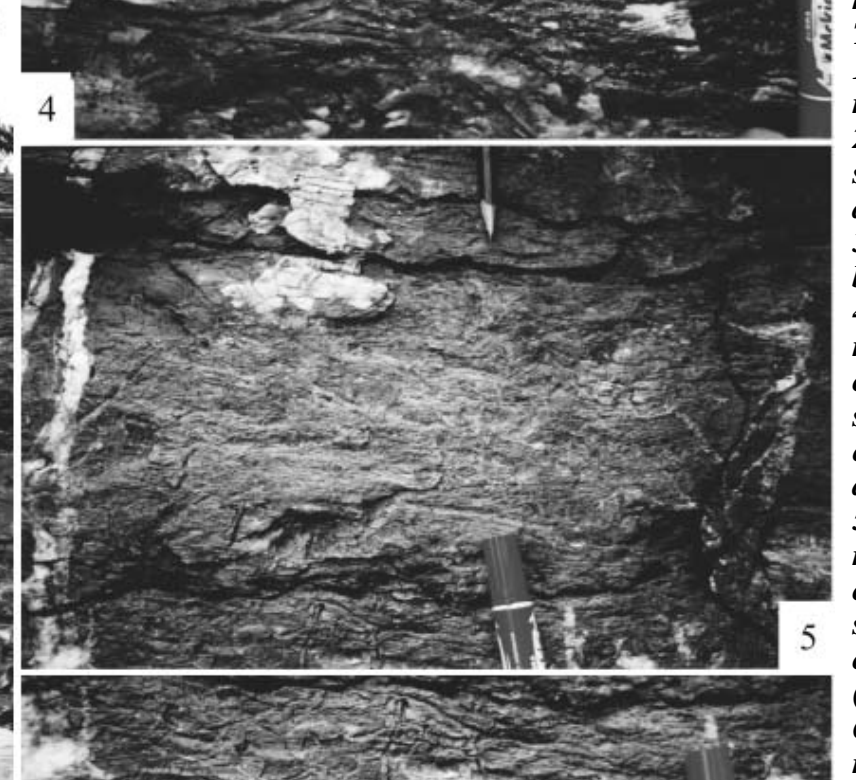

Figure 6 Sedimentary sequence and allochthonous micro-sequence. 1. One part of cross-section of Wanlong Fm.: 1-6, Autochthonous micro-sequence of MT, 7-8, Transition part, few Molar-tooth, 11-15, Terrigenous sedimentary micro-sequence of MT;

2. Allochthonous MT beds, with scour-surface (e.g. marked by arrows);

3. Allochthonous MT beds (marked by arrows);

4. Allochthonous micro-sequence, magnification of sequence (No. 8 of 1), intraclastic MT with crossstratification structure and erosion surface (marked by arrows);

5. Allochthonous micro-sequence, magnification of sequence (No.7 of 1), mimicry-intraclastic MT, showing discontinous lamination of MT and erosion-surface (marked by arrows);

6. Allochthonous micro-sequence, magnification of sequence (No.6 of 1), the lower and middle part are autochthonous MT, the upper part are allochthonous MT (marked by arrows). 


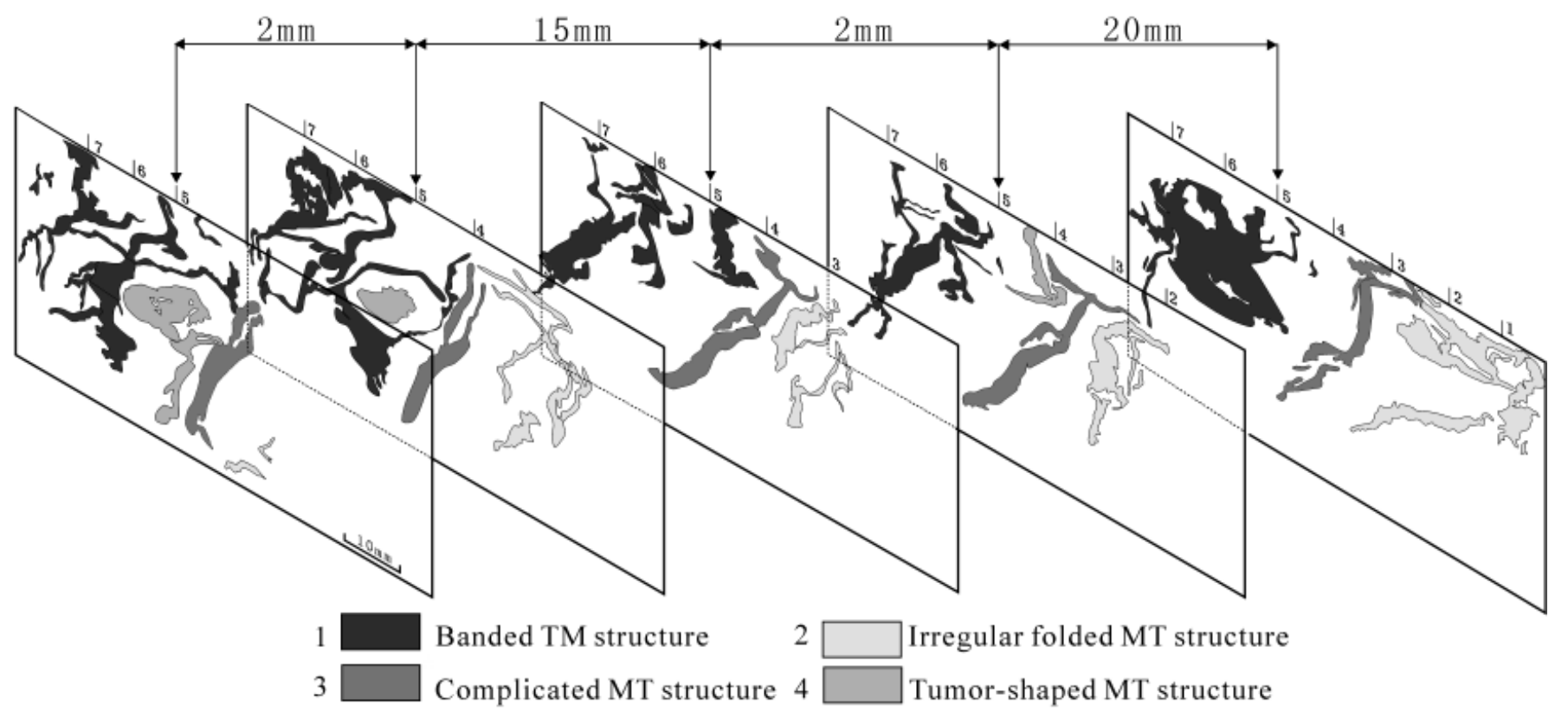

Figure 7 Three-dimensional analysis of Molar-tooth carbonates structural configuration of Sinian in Nanguanling Formation, Dalian, Northeast China.

and $\mathrm{Cr}$, whereas the material comprises peaks of $\mathrm{Si}$ and $\mathrm{Ca}$ only. Most of the MT microsparite in many of macro-structures are homogenous in general, but there are some heterogenous microsparite, for example, some heterogenous microcrystal grains in the dot-line-shaped type were found (Figure 4).

\section{Sequences and microfacies analysis}

\section{Sedimentary succession of carbonate ramp margin}

The environmental interpretation of ancient limestone mostly involves the same facies approach as is used for siliciclastics (e.g. Walker, 1984, Reading, 1986), along with more detailed laboratory studies to identify microfacies.

The Late Precambrian strata of the Hunjiang-Tonghua region and Anhui region were deposits of a ramp margin of the North China platform (Meng and Ge, 1996, 2002). Terrestrial and marine carbonates are very well-developed, e.g. during Wanlong-Badaojiang time when the region concerned was chiefly marked by tidal-flat, platform-margin, gentle slope and steep-slope systems, where the sedimentary succession is composed of three units: the upper ramp (UR) on the platform margin, middle gentle slope (MR) and the deep (lower) gentle slope (DR) (Figure 8 and Figure 9) described below: a) The upper gentle slope of the platform margin is composed of stromatolite limestone, tidal-flat limestone and dolomite.

b) The middle gentle slope consists mainly of sandy limestone and thin-bedded fine quartzitic sandstone. The sandy limestone is marked by an alternation of cross-bedded tidal and wave beds; mostly reflecting deposition in an environment of high-energy, shallow beach and subtidal channel.

c) The deep carbonate ramp is mostly made up of argillo-sparry limestone, bioclastic argillaceous sparry limestone, silty-argillosparry limestone, argillo-sparry shale and nodular limestone, locally forming marly mounds, reflecting deposition in quiet water below storm wave-base.

\section{Microfacies and micro-sequences of the MT carbonates:}

The autochthonous MT carbonates are mainly formed in argillaceous-sparry limestone or silty carbonaceous sparry limestone; they are locally found in grainstone, such as coarse sandy limestone and oolitic limestone. The following aspects are worth noting:
According to the components of MT carbonates and the relationship between them and their sequences, in an upward-shallowing sequence they consist of three units: the lower unit (a), the middle unit (b) and the upper unit (c). The unit a is of argillaceous or micritic lamination and deposited in the quiet water and below the fair-weather wave-base or the storm wave-base. Terrigenous clasts and MT structures were not developed in this unit.

The unit $b$ consists of silty-bearing micritic limestone with irregular laminae or massive structure. In this unit, MT structures are diverse and exhibit the above four types of autochthonous MT. The tumorous MT often become numerous and larger from the lower to the upper part, and they usually developed in the lower part of this unit. The subvertically growing banded MT developed in the laminated micritic limestone of this unit, often terminating or being folded in the lithologic change surface. In the homogenous massive micritic limestone of this unit there often formed smooth filamentous MT with hook-like end and the extended MT. The hook-like structures occur in the lithologic change surface when they stretched to the upper part.

The unit c consists of clastic grainstone and allochthonous MT bedding. The clastic grainstone was caused by grainstones that suffered from the scouring of wave and current, and then formed troughs which was filled with clastics and allochthonous MT. There remained no autochthonous MT structure in the Unit c. But the allochthonous MT bedding appears in the erosion surface and the scour channels ( Figure 6-2), and sometimes some trace-fossils also occur in this unit.

Based on the MT carbonates classification presented above and study of both cyclic and facies sequences in the Wanlong Formation, a detailed subdivision of the MT microfacies is given in Figure 10, which also illustrates the microfacies (from MF1 to MF11) of the MT carbonates, shown by the SF (the function of sedimentary filling of the microsparite) and DC (the function of the depositional covering of the inlet sediments, as caused by current wave and storm current)

According to the detailed analysis of the microfacies and cyclic sequences of the stratigraphic section from Wanlong Fm., the relationship between cyclic sequence and sea level change is clearly shown in Figure 11. 


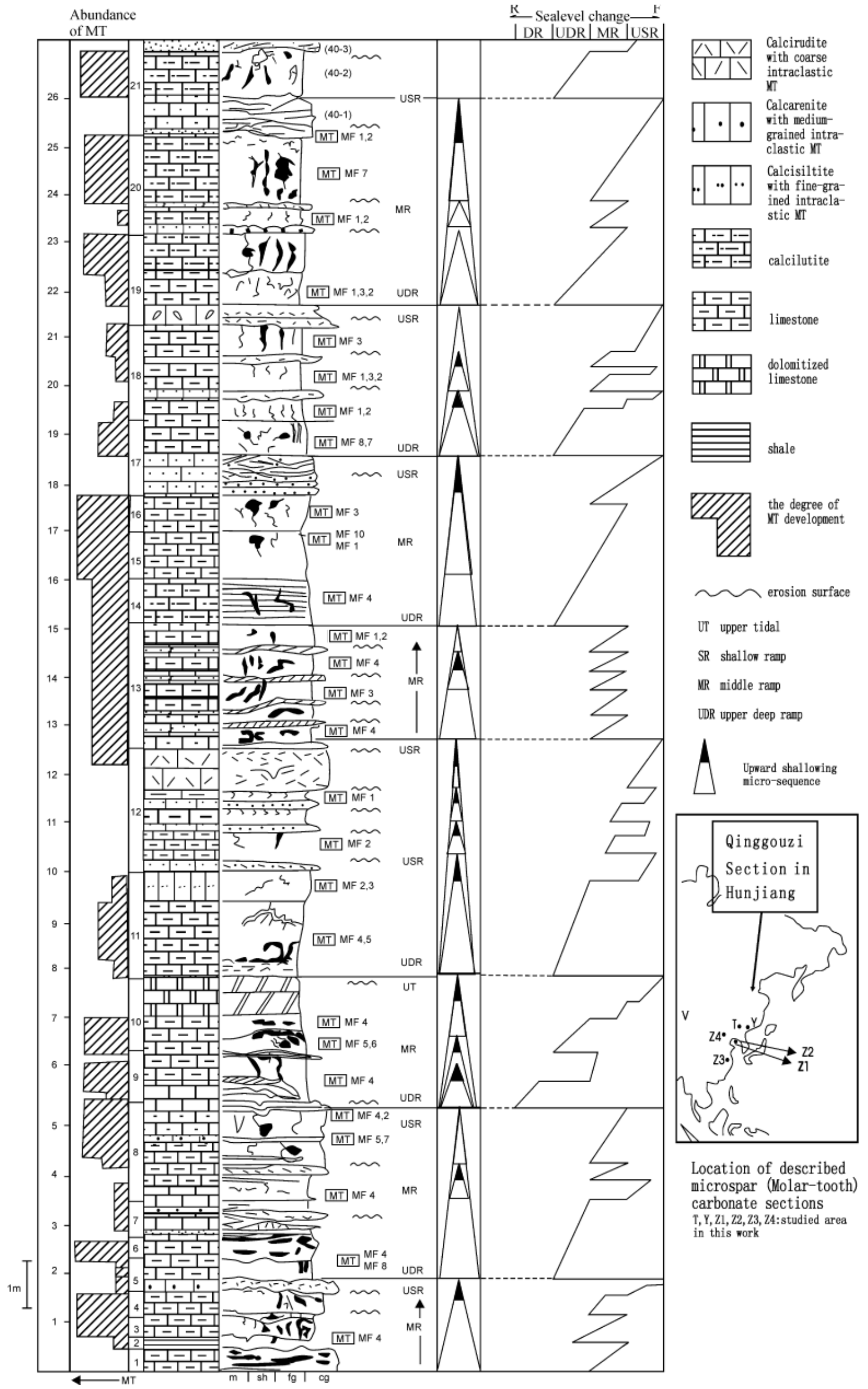

Figure 8 The carbonate micro-sequences and distribution of Molar-tooth (MT) structure from Wanlong Formation in Jilin Province. 


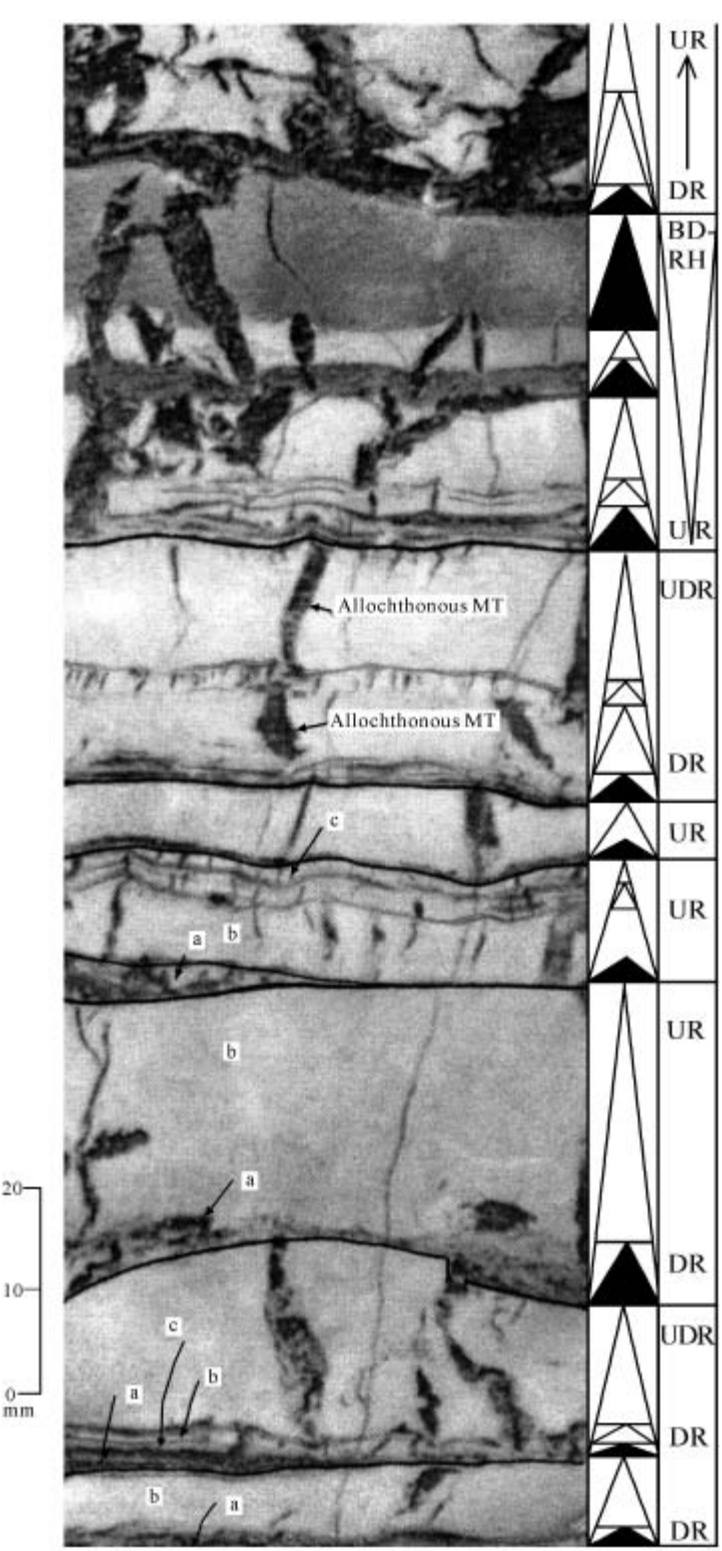

Figure 9 Microsequence of deep ramp allochthonous MT carbonate, an example from Jiudingshan Formation in Anhui Province.

a-intraclastic graded bedding of MT;

$b$-fine-grained mudlimestone;

$c$-mudlimestone.

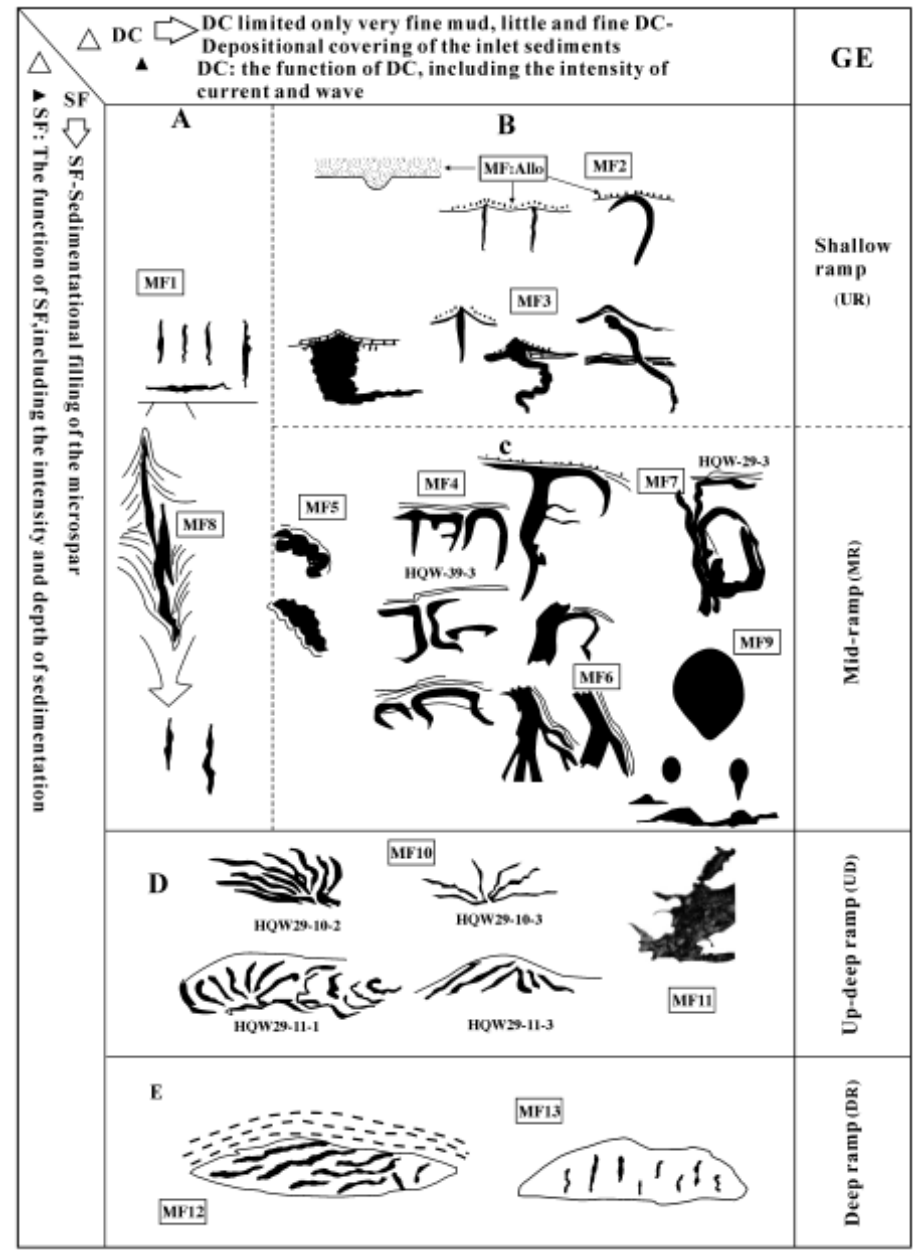

Figure 10 Microfacies and sedimentary environment of Molar-tooth carbonates in North China.

A - [MF1, MF8, MF9]. MT grew freely up and down, they haven't been influenced by coarse-grained sediments, but on the contrary the growing MT structure has an effect on the type of the syn-sedimentary lamination; $B-[M F 2, M F 3]$. The top of MT growth was limited by coarse-grained DC inset Sediments;

C - [MF4, MF5, MF6, MF7]. MT growth was only limited by fine DC inset Sediments;

D- [MF10, MF11], MT growth suffered from some forcing (for example, Long term storm, etc.);

E- [MF12, MF13]. MT growth was under the influenced belt, [MF12],

MT grew in nodular limestone with covered by storm induced allochthonous MT clastic flow.

HQW - (Wanlong Fm., Qinggouzi section, Hunjiang); GE - geological environment.

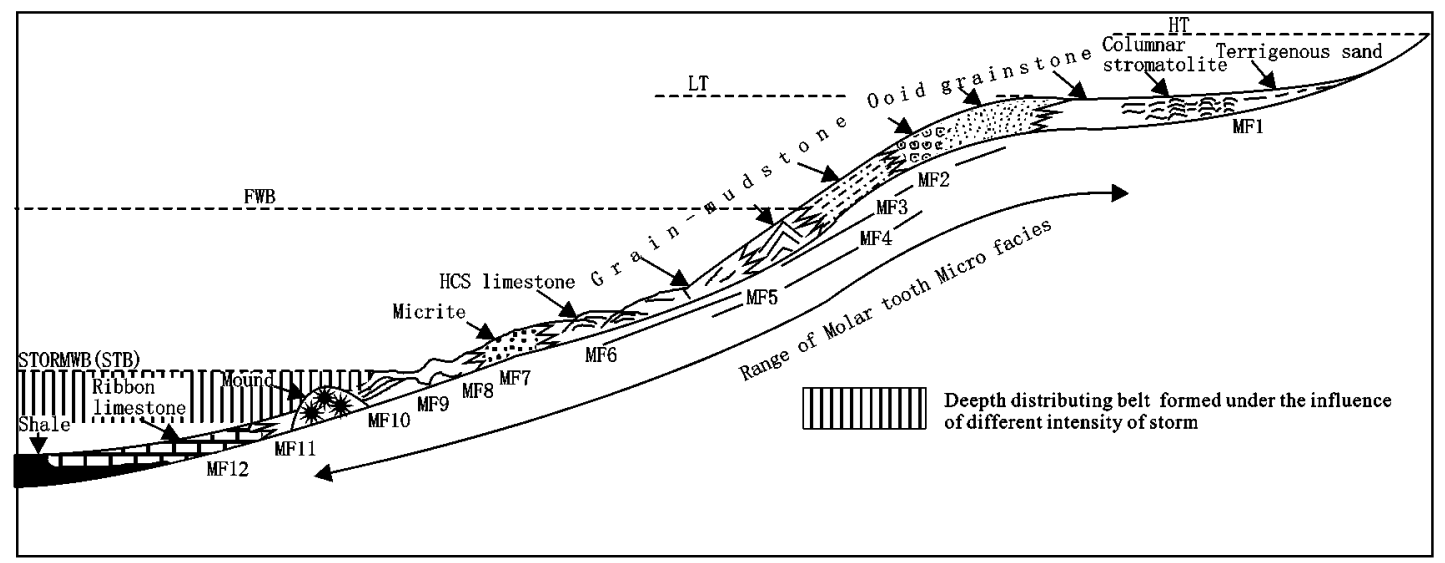

Figure 11 The range of paleoenvironments in which Molar-tooth MF1MF12 occurred.

HCS - Hummocky crossstratification;

FWB - Fine weather wave base;

LT - Low tidal; HT-High tidal. 


\section{The geological significance of MT carbonates}

\section{Specific time-range of MT carbonates}

Within the Archaeozoic-Early Proterozoic carbonates calcite cement is commonly and typically sheet-like to fibrous calcite spar and fanlike micro-digitate travertine stromatolites. MT structures are rarely seen within the oldest carbonates, as they mostly appeared around 1500-1600 Ma. This coincides with the appearance of bedded evaporites and is close in time to the disappearance of the micro-digitate travertine stromatolites (Grotzinger, 1989, James, 1998).

The later half of the Late Proterozoic marks the disappearance of MT carbonates, and this appears to correspond to the large $\delta^{13} \mathrm{C}$ anomaly in the stratigraphic record (Knoll and Walter, 1992; Knoll et al. 1995, Kaufman et al. 1997). There are no MT carbonates in the Phanerozoic and according to James (1998), MT degeneration is related to two biotic changes: biomineralization and bioturbation. Skeletal calcification developed in the Late Proterozoic (pre-550 $\mathrm{Ma}$ ), and skeletal invertebrates and calcified bacteria became more varied and diverse. Hence, calcified skeletons replaced carbonate precipitation, and the latter process was so decreased that MT structures finally stopped forming. The increasing bioturbation also helped to reduce the formation of MT structures; bioturbation probably destroyed the microbial sheet which often covered the seafloor (Seilacher and Pfluger 1994; Narbonne 1998). These microbes (eucaryotes), and especially the ultra-microbiota may have been the main cause of the formation of MT structures.

G. A. Shields $(1999,2001)$ proposed that the decrease in $\mathrm{CaCO}_{3}$ saturation and/or an increase in the concentration of precipitation inhibitors (those include $\mathrm{Fe}^{2+}, \mathrm{Mg}^{2+}, \mathrm{SO}_{4}{ }^{2-}$ and $\mathrm{PO}_{4}{ }^{3-}$ ) in Mid-Neoproterozoic sea water may have contributed to MT carbonate disappearance.

Some scholars (Qiao and Gao, 1999), who stick to the seismic origin for MT, attempt to prove that there were MT carbonates during Cambrian to Ordovician periods. Their so-called MT structures should be regarded as dissolution pipes and dissolution evaporite signifying a drought climatic event (Meng and Ge, et al. 2002).

This study shows that the maximum spike distribution of the Middle-Late Proterozoic MT limestones occurred in 1000 or 900 to 600 Ma period.

\section{Palaeo-environmental significance of MT carbonates}

MT carbonates are especially well-developed in China, particularly in Liaoning and Jilin provinces, and they occur in a variety of sedimentary facies. From the sequence statistics and analysis of megascopic microfabrics, a sedimentary model for MT carbonates has been drawn up. The MT carbonates occur from the basin margin's sublittoral zone through to the basin center. Various megascopic microfabrics may serve as useful environmental markers. As an example the Qinggouzi section in Hunjian and the Jiudingshan Formation in Lingbi show the following features (Figure 9 and Figure $10)$ :

The shallow ramp deposits (SR illustrated in Figure 2 and Figure $8 \mathrm{~A}$ and $\mathrm{B}$ ) contain mainly sandy and conglomeratic limestones with spherulites of argillo-sparry limestone, but MT structures are only rarely developed. The stiped MT occurs locally. In shallow foreshore facies there occur MT fragments, broken in site or transported, forming laminated "sparry clastic" grainstone (Figure 6-2 and 3). The middle gentle ramp facies (MR) is composed of grey, thick-bedded argillo-sparry limestones, intercalated with thin intraclastic limestone and conglomeratic limestone, with hummocky bedding. The argillo-sparry spherulitic limestones commonly contain large to medium-sized ptygmatically folded MT structures .

The upper deep ramp deposits (UDR) are composed of an alternation of silty limestone with cross-bedded laminae and argillo- sparry limestone, and large-scale irregularly and vertically distributed MT structures are common. The input of clastics was unfavorable to the formation of MT structures. In the tidal-flat facies with planar stromatolites, where the supply of terrestrial clastics was restricted, MT structures were rarely formed. They were also very rarely seen in neritic stromatolitic carbonate zone. They were more common in lime-mudstone deposited in deep-water. They may be disrupted by waves, tides and storms, forming tidal channel crossing-bedding and tempestite beds of broken MT intraclasts (i.e. allochthonous MT carbonates, see Figure 9 and Figure 10D).

In the deeper part of the basin, there was no clastic deposition, and because the water was deeper (about $>100 \mathrm{~m}$ ), so rarely microbial sheet covered the seafloor, hence there formed muddy argillaceous shale or mud limestone with MT structures, such as MT-bearing nodular limestone and MT-bearing bioherm (Figure 9DR and Figure 10E).

MT structures typically formed in subtidal environments and occurred especially in the basal parts of shallowing-upward cycle.

\section{MT limestones and their role in the origin and evolution of life}

Eucaryotes appeared before $1300 \mathrm{Ma}$ (Schopf, 1978) or 1300-1600 Ma (Sokolob, 1979) and it is generally considered that since then life evolved gradually (Margulis 1970). According to Zhu, Xing, Zhang et al. (1994), protozoans might possibly have appeared earlier than generally supposed as based on the following reasons: (1) Though the Ediacara fauna (700-600 Ma) was more primitive and simpler than the Cambrian metazoans, palaeoecologically speaking, they included pelagic to benthic types, embracing many phyla, such as Coelenterata, Porifera, Annelida, Brachiopoda and Arthropoda, all of which were soft-bodied, but they had reached a fairly high level of metazoan evolution; (2) In the Upper Sinian of Xu-Huai region (ca 700-600 Ma), coelenterates, sponge spicules, annulates and brachiopods were found, while in the Lower Sinian (Changlingzi Fm. in S. Liaoning) undoubted Vermes (Sabellidites and Palevlian) occurred. The Changlingzi Fm yielded an isotopic age of $750 \mathrm{Ma}$, proving the existence of pre-Ediacara metazoans. In many cases it appears that the inner and middle ramp (sea-floor) was covered by a microbial foam, which is considered a pre-requisite condition for the formation of MT structures, and probably the exploding interval for the development of MT structures was 1500-1600 Ma.

\section{Discussion on the origin of the MT carbonates}

\section{Review on the origin of the MT carbonates}

Molar tooth structures have been receiving wide attention in view of their possible close connection with organic evolution (Kaufmann, 1997, Knoll et al. 1972, James et al. 1998). Some people believe that MT structures resulted from underwater sediment-shrinkage (Horodyski 1976, Knoll and Sweet 1990, Pratt et al. 1999, Winston, Don et al. 1999), but others consider that earthquakes caused the dewatering (Pratt 1992, Fairchild et al. 1997).

Although cracks formed by dewatering or contraction might resemble MT structures, they lack the interior fillings. In cross-sections MT structures are generally contortedly-folded. Under the scanning microscope the MT filling material is distinctly shown and composed of fine-grained crystalline calcite, which grew perpendicular to cracks. According to Hofmann's observations (1985) the microspar filling MT structures is identical to that filling the nondeformed spherical or cylindrical organic fossils such as Chuaria and Tawuia. According to experiments of Furniss et al (1997), the muds produced molar tooth-like cracks only when the surface was sealed. James (1998) proposed: "the most parsimonious explanation is that the muds were covered by microbial mats. The implication of 
this interpretation is that Molar-tooth is the testimony to what we have long suspected, that the muddy carbonate seafloor in intertidal and most subtidal environments was veneered with microbial scum restricted to the Mesoproterozoic and Neoproterozoic most likely reflected the evolutionary acme of microbial communities suited to this environment. Our observations imply that this community did not extend into deep subtidal or basinal settings, possibly because it was phototrophic".

Some seismic origins have been held by some scholars, about which several points should be mentioned. Firstly, Roep (1992) emphasized that in a carbonate-depositing basin the presence of pillow-beds is the strongest evidence of earthquakes, but so far no such rock structure has been reported within MT carbonates in our study area. Secondly, it is known that liquefaction of sandstone is common in an area of seismite formation (Allen 1986). Within coarse-grained sandy sediments liquefaction occurs comparatively easily, but not so easily in fine -grained rocks (fine silty sands, fine argillo-calcarious mud and mudstone). Dewatering structures finally only dewater in coarse-grained sediments, but rarely in fine-grained rocks; MT limestones are originally very rarely granular. Thirdly, it is well-known that tectonically related seismicity occurred throughout the geological record, whereas MT limestones are limited within the Middle and Late Proterozoic. Some Chinese scholars have considered that MT limestones occur preferentially in the ancient Tan-Lu fault zone. However, a majority of workers hold that the Tan-Lu fault was active mainly during the Meso-Cenozoic times, as a result of strikeslip tectonism (Xu Jiawei et al. 1994). Employing the Milankovich's cycle concept, the present authors have prepared a precise isochronic palaeogeographic maps for the North China platform from lower Cambrian to upper Permian (Meng Xianghua et al. 1995, 1996, 2002), which shows that there is no relationship between the facies distribution plus sediment thickness with the Tan-Lu fault.

Hence, the origin of MT carbonates may be summarized as follows: (a) Spatially speaking, MT carbonates were formed in extremely ancient shallow seas on the carbonate platforms and lower and middle ramp environments, all of which were favorable habitats for eucaryotes; (b) Temporarily speaking these structures began to form before 1500-1600 Ma (James 1998), flourishing to a maximum during $1000 \mathrm{Ma}$ or $900 \mathrm{Ma}$ to $650 \mathrm{Ma}$ (our information). According to Zhu (1993), single-celled organisms appeared around the beginning of the Proterozoic (1800 Ma), while texturally complex eucaryote multi-cellular algae appeared in the middle stage of the Middle Proterozoic 1300 or 1300-1600 Ma. Metazoans might have appeared around 1000-650 Ma. All of these important intervals are closely connected with the occurrence of the MT limestones; in other words, these limestones appeared step by step in accordance with the evolution and decline of the earliest life in geological history. Hence, the formation of Middle to Late Proterozoic MT limestones depends on the then developing eucaryotes. The abrupt disappearance of MT structures within the latest Proterozoic as mentioned above is probably related to biomineralization and bioturbation.

\section{Some deliberations on the origin of MT}

MT appears most abundantly in muddy or silt-bearing micritic limestone, a most important MT limestone. Curved banded type, complicated sheet-like type and dotted type MT structures mostly developed in this MT limestone. The authors think that the following features of this MT limestone may help to trace the origin of the MT structure.

a) The MT structure growing perpendicular to lamination usually spreads widely in its middle part and taper both upward and downward (Figure 12). Such a distinctive feature has no relationship to waterescape structure and others caused by gravity-flow.

b) There usually appear deformed MT structures and thickening or/and fragmentation caused by fold superimposed between the laminae of the siltstone (or silt)-bearing or none muddy micritic limestones. The phenomena and features are just the same as Smith described and discussed detailedly in 1967, they formed by the differentiation of argillaceous laminae with sand and mud

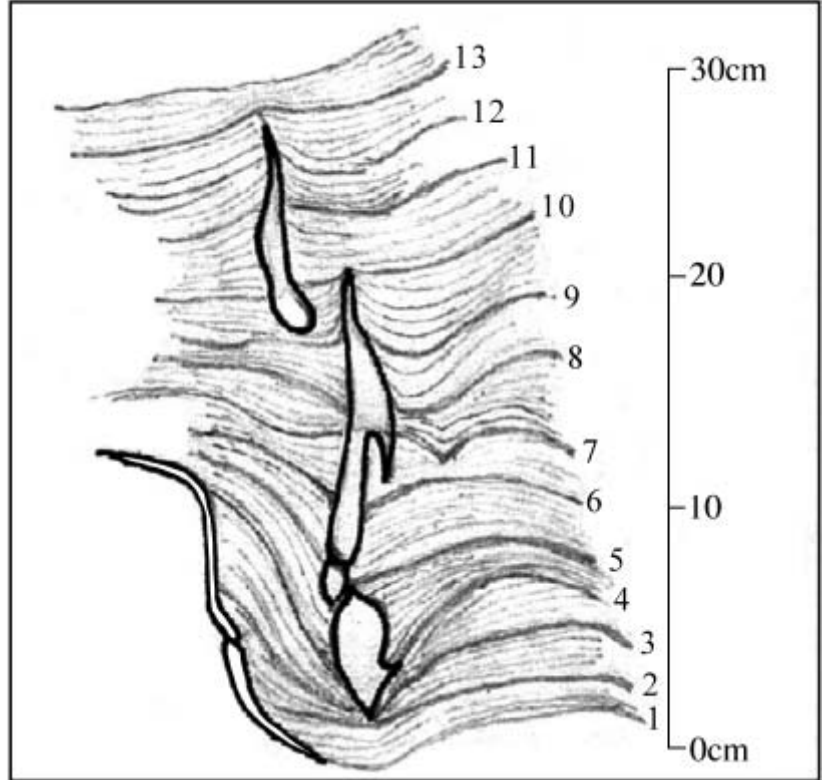

Figure 12 The relationship between microspar (Molar-tooth) structure and the lamina of micritic limestone: a neap-spring super micro-cycle sequence from Nanguanling Formation in Fuzhou, Liaoning Province, Northeast China.

content and of the water content, plasticity, stickiness and other characters of the sediments. The authors think that the deformed MT, thickening and fragmentation caused by fold superimposition could occur without any other external factors such as earthquake and so on.

c) There usually occurs the distorted lamination of the enclosing rock forming extruded ridge caused by different compaction at the top and bottom of the MT structure. This may be interpreted as follows: MT structure is composed of pure microsparite, their crystallization and solidification being stronger and earlier than the enclosing rocks that are muddy limestone, so in the process of compaction, MT structure usually appeared as a ridge framework, which is unlike the product of seismic liquefaction as proposed by some scholars holding seismic origin.

d) The last problem is the development of MT structure and the number of lamination that it has penetrated. Take an example of Figure 12, which shows that during the forming of MT structure, the laminae number that it penetrated reached more than 60 (Figure 12). Based on the above analysis, the lithofacies of these laminated micritic limestone reflects a sedimentary environment of shallow-marine deeper gentle slope. Based on the modern carbonates' depositional ratio $(0.01-2.5) \mathrm{m} / 1000 \mathrm{a}$, the average ratio is $1 \mathrm{~m} / 1000$ a (Tucker, 1990), the forming time range of a millimeter-scale lamina (Figure 2) is 10-300a, the average time limit is 100 years. If the MT structure is related to seismic events, then how did the seismic event influence the MT structure's forming-did it need several to one hundred years? Obviously, it is impossible.

The latest researches on bio-molecular structures (Zhou 1998 , Masterton and Slowinski 1980) indicate that the second-level structural unit of the basic component of life is protein (molecular peptide chain of $\alpha$-spirochaeta and $\beta$-fold). Both of these have electronmagnetic wave. The protein molecule is life-type amino acid. Peptid chain has two ends, amino-group $\mathrm{NH}^{3}$ and carboxyl $\mathrm{COOH}$, which are $\mathrm{pH}^{+}$and $\mathrm{pH}^{-}$respectively. The electric current is produced while the enzymes on the two ends activate the protein-molecule; once the protein peptid chain performs an electric movement, it forms a current, which produces an electron-magnetic wave whose length is equivalent to the microwave range. The energy generated by the micro-bioelectromagnetic wave may activate the chemical reaction of the surrounding medium. 
The implication for the theory of biowave might be a new way to explain the mechanism of carbonate precipitation within the molartooth structure.

During the Middle and Late Proterozoic the atmosphere and hydrosphere were still low in $\mathrm{Pco}_{2}$ content and the $\mathrm{pH}$ value was still acidic. The living protein, and its energy generated by the microbiowave may have helped to increase the $\mathrm{pH}$ value and so cause chemical precipitation of pure micro-sparry carbonates; at the same time $\mathrm{CO}_{2}$ would have increased and the preserved space could lead to the formation of the cracks of the MT structures. Some MT limestones contain as much as $50 \%$ of the total amount of carbonate.

To summarize, it is suggested that a great significance should be attached to MT structures, which serve as a key to Precambrian biological and geochemical events. They might be a link of the revolutionary changes in the biosphere, which heralded the appearance of the complex multi-cellular animals of the Late Precambrian.

\section{Acknowledgements}

The work reported here was supported by the Key Program of International Scientific and Technological Cooperation of Ministry of Science and Technique (2001CB 711002), National Natural Science Foundation of China (No. 4017043) and the International Geological Correlation Programme (IGCP) project 447. Our thanks are due to Professor Yang Zunyi, Professor Hao Yichun and Professor Maurice Tucker for their comments and help on this manuscript.

\section{References}

Allen, J. R. L., 1986, Earthquake magnitude-frequency, epicentral distance, and soft-sediment deformation in sedimentary basins. Sediment.Geol., $46,67-75$.

Bauerman, H., 1885, Report on the geology of the country near the fortyninth parallel of north latitude west of the Rocky Mountains: Geological Survey of Canada, Report of Progress 1882-1884, pt. B., 1-4.

Burchette, T. P., and Wright., V. P., 1992, Carbonate ramp depositional systems: Sedimentary Geology. v.79, 3-58.

Calver, C. R., and Baille, P. W., 1990, Early diagenetic concretions associated with intrastratal shrinkage cracks in an Upper Proterozoic dolomite Tasmania, Australia: Journal of Sedimentary Petrology, v.60, 293-305.

Chambers, L. A., Trudinger, P. A., 1979, Microbiological fractionation of stable sulfur isotopes: A review and critique. Geomicrobiology Journey, v. 1 , no. $3,249-293$

Droser, M. L., 1991, Ichnorabric of the Paleozoic Skoithos ichnofacies and the nature and distribution of Skolithos pipe rock: Palalos., v.6, 316-325.

Eby, D. E., 1975, Carbonate sedimentation under elevated salinities and implications for the origin of molar-tooth structure in the middle belt carbonate interval (late Precambrian), northwesten Montana (abstract): Geoiogical Society of America. Abstracts with Program, v. 7, 1063.

Fairchild, I. J., Einsele, G., and Song, T., 1997, Possible origin of molar tooth structures in Neoproterozoic carbonate ramp deposits , North China: Sedimentology. v.44, 611-636.

Farmer, J. D., 1992, Grazing and bioturbation in modern microbial mats, in Schopf, J. W., and Klein, C., eds., The Proterozoic Biosphere: A Multidisciplinary Study: Cambridge, U.K., Cambridge University Press, 295298.

Furniss, G., Rittle, J. F., and Winston, D., 1997, Gas bubble and expansion crack origin of "molar tooth" calcite structures in the Middle Proterozoic Belt Supergroup,Western Montana: Journal of Sedimentary Research. v.68, 104-114.

Ge Ming, Liu Yongqing and Meng Xianghua, 1996, Field trip T313 guidebook of the 30th International Geological Congress: The depositional sequences and the evolutionary history of the North China carbonate Platform of early Paleozoic, The Geogical Publishing House, Beijing.

Ge Ming, Meng Xianghua and Tucker, M. E., 1995, The Changshanian maximum sea flooding event and its gobal correlation, Chinese Science, Bulletin 40, 818-821.

Grotzinger, J. P., Bowring, S. A., Saylor, B. Z. and Kaufman, A. J., 1995, Biostratigraphic and geochronolo-gicconstraints on early animal evolution.: Science, v.270, 598-604
Hayes, J. M. et al., 1983. Precambrian organic geochemistry, preservation of the record, in Schof, J. W.eds, Earliesst Biosphere: Its origin and Evolution.

Hong Zuomin, Huangzhengfu et al., 1991, Upper Precambrian in southen Liaodong Peninsula. Geological Memois sreies 2 no.14, Geological Publishing House, Beijing.

Horodyski, R. J, 1976, Stromatolites of the upper Siyeh Limestone (Middle Proterozoic), Belt supergroup Glacier Nationa Park, Montana: Precambrian Research. v.3, 517-536.

James, N. P., Narbonne, G. M. and Sherman, A. G., 1998, Molar-tooth cabonates: Molar-tooth carbonates: shalllow subtidal facies of the MidLate proterozoic: Journal of Sedimentary Research, v. 68, 716-722.

Kaufman, A. J., Knoll, A. H., and Narbonne, G. M., 1997, Isotopes ice ages and terminal Proterozoic Earth history. National Academy of Sciences [U.S.A], Proceedings. v. 94, 6600-6605.

Knoll, A. H., and Walter, M. R., 1992, Larest Proterozoic stratigraphy and Earth history: Nature. v.365, 673-678.

Knoll, A. H., Kaufman, A. J., and Semikhatov, M. A., 1995, The carbon-isotopic composition of Proterozoic carbonates: Riphean successions from northwestern Siberia (Anabar Massif, Turukhansk Uplift). American Journal of Science. v.295, 823-850.

Kuznetsov, V. G., 1979, Paleozoic Reef Formation in Russia and its surrounding countries, P:5-6.

Masterton, W. L., and Slowinski, E. J., 1980, Chemical principles. Peking University Press

Meng Xianghua et al., 1996, Study on sea-level fluctuation geodynamics of carbonate depositional cycles in the North China Platform, Acta Sedimentologica Sinica, 14:2, 29-40.

Meng Xianghua and Ge Ming, 1996, Sinian-Ordovician paleogeography, cyclicity-rhythm and sedimentary events of China. International Academic Publishers

Meng Xianghua, Ge Ming, and Liu Yongqing, 1996, Field trip T224 guidebook of the $30^{\text {th }}$ International Geological Congress: The Cambrian deposition facies, sequence stratigraph, and the high-frequency cyclic sequences of the carbonate platform at the Western Hill, Beijing. Geogical Publishing House, Beijing.

Meng Xianghua and Ge Ming, 1993, Sedimentary basin and depositsequence. Geological Publishing House.

Meng Xianghua and Ge Ming, 1993, Study on intrabasinal deposits. Petroleum Industry Press.

Meng Xianghua and Ge Ming, 2002, Sequences, Events And Evolution of Sino-Korea Plate. Science Press

Meng xianghua and Ge ming et.al, 2002, Cyclic sequence of evaporite rocks and origin discussion of dissolution pipes structure of low Cambrian in Dalinzi formation and the discussion of Proterozoic Molar-tooth carbonate. Chinese Science Bulletin (in publishing).

Narbonne, G. M., and Aitken, J. D., 1995, Neoproterozoic of the Mackenzie Mountains, northwestern Canada. Precambrian Research, v.73, 101-121.

Narbonne, G. M., 1998, The Ediacara biota: A terminal Neoperterozoic experiment in the evolution of life: GSA today. v. 8, no. 2, 1-6.

O'Connor, M. P., 1972, Classification and environmental interpretation of the cryptalgal organo-sedimentary "molar-tooth" structure of the Precambrian Belt-Purcell Supergroup. Journal of Geology, v. 80, 592-610.

Pratt, B. R., 1992, Shrinkage features ("molar tooth" structure) in Proterozoic limestons new model for their origin through synsedimentary earthquakeinduced dewatering (abstract). Geological Society of America, Abstracts with Program, v.24, no.7, 53.

Pratt, B. R., James, N. P., and Cowan, C. A., 1992, Peritidal carbonates, in Walker, R. G., and James N. P., eds., Facies Models: St. Johnis Newfoundland, Geological Association of Canada, 303-322

Pratt, B.R., 1999, Gas bubble and expansion crack origin molar-tooth calcite structures in the Middle Proterozoic Belt Supergroup, Western MontanaDiscussion, Journal of Sedimentary Reseach. Vol.69, 1136-1140.

Qiao, X., Song, T., Gao, L., Peng, Y., Li, H., Gao, M., Song, B., and Zhang, Q., 1996, Seismic sequence in Carbonate rocks by vibrational liquefaction. Acta Geological Sinica, 7, 243-265.

Qiao Xiufu and Gao Linzhi, 1999, Neoproterozoic and Early Paleozoic seismic disaster Events in the North China Platform and their relationship with Rodinia, Chinese Science Bulletin, v. 44 (16): 1753-1757.

Rainbird, R. H., Jefferson, C. W., Hildebrandt, R. S., and Worth, J. K., 1994 The Shaler Supergroup and revision of Neoproterozoic strtigraphy in the Amundsen Basin, Northwest Territories: Geological Survey of Canada. Paper 94-1A, 61-70.

Reading, H. G., 1986, Facies. in Reading, H. G., ed., Sedimentary Environments and Facies, Blackwells, Oxford, 4-19. 
Roep, T. B. and Everts, A. J., 1992, Pillow-beds: a new type of seismites? An example from an Oligocene turbiditefan complex, Alicante. Spain.Sendimentology, 1992, 39, 711-724.

Sami, T. T., and James, N. P., 1996, Marine preciptation as basic building blocks of Middle Proterozoic shelf carbonates: Journal of Sedimentary Research. v. 66, 209-222.

Seilacher, A., and Pfluger, F., 1994, From biomats to benthic agriculture: a biohistoric revolution, in Krumbein, W. E., Paterson, D. M., Stal, L. J. et al., Biostabilization of Sediments: Universitat Oldenburg. Bibliotheks and Information system. 97-105.

Smith, A. G., 1968, The origin and deformation of some "molar tooth" stuctures in the Precambrian Belt-Purcell Supergroup: Journal of Geology. v.76, 426-443.

Schopf, J. W., 1978, The evolution of the earlist cells, Scientific American . $239,110-138$

Sheilds, G. A., 1999, Working towards a new stratigraphic Calibration scheme for the Neoproterozoic Cambrain, Eclogae Geological Helvetiae, 92.

Tucker, M. E., and Wright, V. P., 1990, Carbonate sedimentology. Oxford Blackwell Scientific Publications, 33-69.

Tomas, E., and Creighton, 1984, Proteins: Structure and Morlecular Principles. W. H. Freeman and Company, New York, 234.

Walker, R. G., 1984, General introduction: facies, facies sequences and facies models, in Walker, R. G. ed, Facies Model. Geoscience Canada, pp.1-9. .

Winston Don, Rittel John, F., and Furniss George, 1999, Gas bubble and expansion crack origin molar-tooth calcite structures in the Middle Proterozoic Belt Supergroup, Western Montana Reply. Journal of Sedimentary Reseach, v.69, no.5, 1140-1145.

Xu Jiawei et al., 1994, Tectonic models of the Tan-Lu Fault Zone, Eastern China. International Geological Review, v. 36, 771-784.

Zhou Kangjin, 1998, Biowave: essence of living action in Shi Baohang ed, New Explorations of Geological Sciences in China. Petroleum Industry Press.

Zhu Shixing, Xing Yusheng, Zhang Pengyuan et al., 1993, Biostratigraphic sequence of the Middle-upper Proterozoic on North China Platform. Geological Publishing House, Beijing.
Meng Xianghua, Professor and supervisor of Ph.D. students and the Superintendent of the Institute of Sedimentary Basin, China University of Geosciences. He is also Leader of IGCP447: Carbonates and the Evolution of the Earth in the Proterozoic. His major research interests include sedimentology, lithofacies and paleogeography, geotectonics, paleostructure, and basin research.

\begin{abstract}
Ge Ming, Professor of the China University of Geosciences. She works on sedimentology, sequence stratigraphy, and paleogeography. Her scientific interest is focused on carbonates of Proterozoic and Phanerozoic, evolution of the Earth, plate tectonics, and sedimentary events. She is Secretary General of IGCP447: Carbonates and the Evolution of the Earth in the Proterozoic.
\end{abstract}
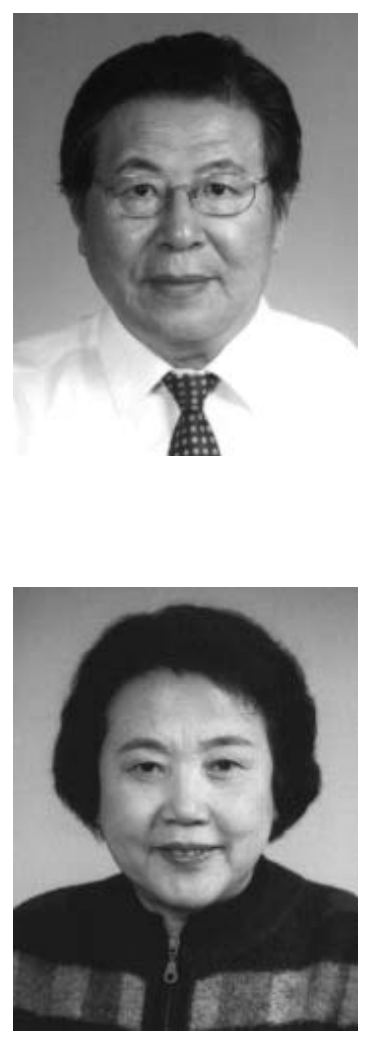

\title{
CALL FOR PAPERS
}

Episodes is the quarterly science and news journal of the International Union of Geological Sciences (IUGS). It focuses on the publication of results of scientific research and other information addressing issues of interest to the global earth-science community. Special emphasis is given to topics involving geological aspects of population growth and economic development and their resulting impacts on or implications for society. As the principal publication of the IUGS, Episodes also carries information about IUGS scientific programs and activities to the extent necessary to communicate effectively with the worldwide IUGS constituency.

Contributions of the following types of manuscripts are here solicited:

- review papers

- scientific articles

- conference reports

- news and views

- letters to editor

- book reviews

- information on training courses (especially those geared to participants from developing countries)

- noteworthy new publications, including national or regional geologic maps

Episodes also invites photos or other images for the front cover. Photos must be of high technical quality and tell an interesting geological story. A color transparency and one color print (at least $9 \mathrm{~cm} \times 12.6 \mathrm{~cm}$ ) are required for submission, which should be supplemented with a short explanatory paragraph (no more than 100 words).

Please address all contributions to:

\author{
The Editor \\ Episodes \\ P. O. Box 823, 26 Baiwanzhuang Road \\ 100037 Beijing, CHINA \\ Tel: +86-10-68320827; +86-10-68329084 \\ Fax: +86-10-68328928; \\ E-mail: episodes@public2.bta.net.cn.
}

